\title{
Analisis SWOT terhadap Strategi Penjualan Smartphone Xiaomi dan Vivo
}

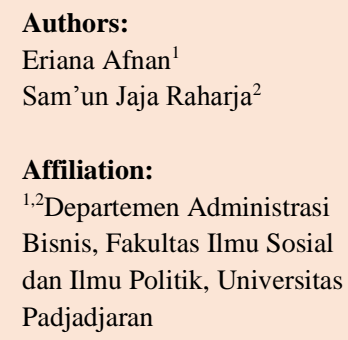

Corresponding Author: Eriana Afnan

Emails:

1eriana19001@mail.unpad.ac.id harja63@yahoo.com

\section{Article History:}

Received: March 12, 2020

Revised : May 30, 2020

Accepted: June 13, 2020

How to cite this article: Afnan, E., \& Raharja, S. J. (2020). Analisis SWOT terhadap Strategi Penjualan Smartphone Xiaomi dan Vivo. Organum: Jurnal Saintifik Manajemen dan Akuntansi, 3(1), 50-63. doi:

https://doi.org/10.35138/organu m.v3i1.78

Journal Homepage: ejournal.winayamukti.ac.id/ind ex.php/Organum

\section{Copyright:}

() 2020. Published by Organum: Jurnal Saintifik Manajemen dan Akuntansi. Faculty of Economics and Business. Winaya Mukti University.

\section{Pendahuluan} onsep pertama smartphone kabarnya telah ada sejak pertengahan tahun 1970-an. Namun, baru terwujud sekitar 20 tahun setelahnya, yaitu saat International Business Machines Corporation (IBM) meluncurkan 
Simon Personal Communicator yang menunjukkan wajah ke publik pada tahun 1992. IBM Simon layak disebut sebagai smartphone, karena perangkat ini memiliki layar sentuh monokrom, sebuah stylus, dan charging base station. Pada tahun 1996 barulah Nokia mulai memasuki dunia smartphone. Selanjutnya pada tahun 1997 Ericsson merilis smartphone pertamanya yang menjadi kompetitor untuk IBM Simon dan Nokia. Smartphone yang mulanya menyasar pasar enterprise mulai menarget consumer. Kehadiran sistem operasi seperti Blackberry, Symbian, Plam OS hingga Windows Mobile yang telah memiliki kemampuan untuk mengirim email dengan internal kian memengaruhi perubahan gaya hidup penggunanya. Hal ini pun terjadi di tahun 2000-an, tepatnya dimulai dari tahun 2004 hingga 2007, di mana jumlah pengguna smartphone kian bertambah banyak setiap tahunnya. Software di setiap smartphone pun semakin lama semakin ramah kepada penggunanya, serta aplikasi dan game dari pihak ketiga perlahan juga mulai diminati.

Seiring dengan berkembangnya kemajuan teknologi dan perkembangan zaman yang semakin modern, cara berkomunikasi antarindividu juga mengalami perubahan. Jika pada masa lalu orang berkomunikasi secara lisan dan bertatap muka, sedangkan di era digital seperti saat ini, orang tidak perlu lagi bertatap muka dengan lawan bicaranya karena alat komunikasi seperti ponsel maupun smartphone menjadi perangkat yang mampu mengantarkan pesan dalam hitungan detik. Bentuknya yang begitu praktis dan fungsi yang beragam, ponsel atau smartphone menjadi perangkat yang membuat hidup pengguna menjadi lebih mudah.

\section{Grafik 1. Indonesian Top 5 Smartphone Tahun 2018}

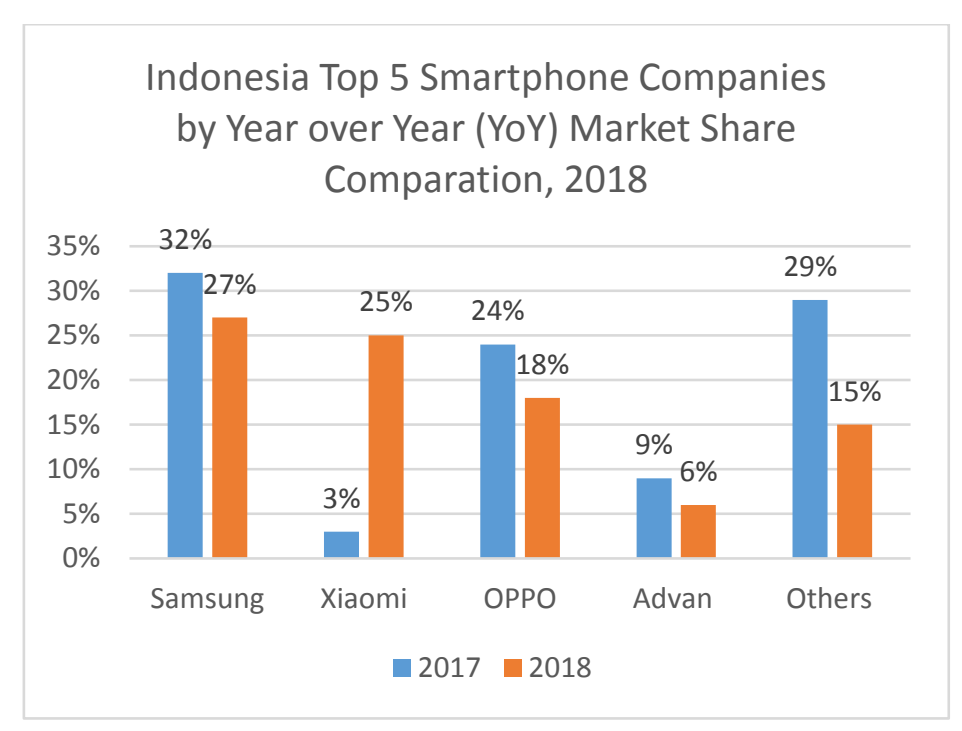

Apabila melihat Grafik 1, di Indonesia banyak sekali perusahaan smartphone yang telah bersaing. Berdasarkan Grafik 1 tersebut, pada tahun 2017 Xiaomi termasuk ke dalam perusahaan smartphone yang memiliki persentase terendah, akan tetapi pada tahun 2018 perusahaan Xioami dapat membuktikan dan berkompetisi dengan perusahaan smartphone lainnya. Hal tersebut terbukti dengan adanya kenaikan yang signifikan dari 3\% pada tahun 2017 menjadi $25 \%$ di tahun 2018. Sedangkan Vivo mengalami hal yang sama pada tahun 2017 memiliki persentase terendah dengan nilai $3 \%$ akan tetapi pada tahun 2018 Vivo dapat menaikan persentasenya menjadi 9\%, walaupun tidak naik secara signifikan tetapi Vivo bisa membuktikan 
bahwa Vivo dapat bersaing dengan para kompetitor.

Dalam penelitian ini kami menganalisis dua perusahaan smartphone yaitu perusahaan Xiaomi dan Vivo. Kedua perusahaan ini memiliki keunikannya masing-masing pada produknya, Xiaomi dan Vivo menjadi primadona di kelasnya. Kedua perusahaan tersebut bersaing dengan terus menciptakan trend handphone yang berkualitas, hal ini membuat Peneliti tertarik untuk membahas kedua perusahaan smartphone dengan menganalisis SWOT untuk menjadi strategi penjualannya. Menurut Kraus, Reiche \& Reschke (2007) mengatakan bahwa peran instrumen strategi pada perusahaan besar dan anggapan bahwa pengambilan keputusan rasional harus berlaku terlepas dari ukuran, praktisi, dan akademisi. Strategi bisnis ini telah dijabarkan dalam berbagai teori dari beberapa ahli, salah satunya adalah Michael Porter. Porter telah menjelaskan suatu skema kategori mengenai dua tipe umum dalam strategi yaitu strategi keunggulan biaya dan strategi diferensiasi (Tanwar, 2013). Oleh karena itu, dalam penelitian ini Peneliti akan fokus pada analisis SWOT pada perusahaan smartphone dengan tujuan untuk melihat bagaimana strategi bisnisnya dan melihat dari sisi internal dan eksternal perusahaan tersebut.

Penelitian ini dilakukan untuk mengetahui analisis SWOT terhadap strategi penjualan pada smartphone Xiaomi dan Vivo dari segi strategi diferensiasi, strategi fokus, strategi kepemimpinan biaya, dan analisis SWOT. Selain itu penelitian ini juga dilakukan untuk mengetahui manakah strategi yang lebih unggul di antara kedua smartphone tersebut. Guna mencapai tujuan penelitian tersebut akan dilakukan pembahasan mengenai strategi berdasarkan aktivitas di dalam strategi penjualan dengan menggunakan analisis SWOT pada kedua perusahaan smartphone Xiaomi dan Vivo. Penelitian ini menggunakan database digital guna menemukan artikel-artikel yang relevan dengan analisis SWOT strategi penjualan pada smartphone Xiaomi dan Vivo.

\section{Kajian Literatur}

\section{Strategi}

Strategi didefinisikan sebagai program untuk menentukan dan mencapai tujuan organisasi. Strategi adalah pola tanggapan atau respon organisasi terhadap lingkungan sepanjang waktu (Tjiptono, 2010). Sedangkan, Rangkuti (2013) berpendapat bahwa strategi adalah perencanaan induk yang komprehensif, yang menjelaskan bagaimana perusahaan akan mencapai semua tujuan yang telah ditetapkan berdasarkan misi yang telah ditetapkan sebelumnya.

\section{Strategi Penjualan/Pemasaran}

Setiap perusahaan mempunyai tujuan untuk dapat tetap hidup dan berkembang. Tujuan tersebut hanya dapat dicapai melalui usaha mempertahankan dan meningkatkan tingkat keuntungan atau laba perusahaan dengan cara mempertahankan dan meningkatkan tingkat keuntungan atau laba perusahaan dengan cara mempertahankan dan meningkatkan penjualannya. Tujuan ini dapat dicapai apabila bagian pemasaran perusahaan melakukan strategi yang baik untuk dapat menggunakan kesempatan atau peluang yang ada dalam pemasaran. Menurut Kotler (2005) strategi pemasaran adalah pola pikir pemasaran yang akan digunakan untuk mencapai tujuan pemasarannya. Strategi pemasaran berisi strategi spesifik untuk pasar sasaran, penetapan posisi, bauran pemasaran dan besarnya pengeluaran pemasaran. Sedangkan menurut Tjiptono (2010), strategi pemasaran merupakan alat fundamental yang direncanakan untuk mencapai tujuan perusahaan dengan mengembangkan keunggulan bersaing yang berkesinambungan melalui pasar yang dimasuki. 


\section{Porter's Generic Strategy}

Menurut (Belton, 2017) dalam buku

Strategi Kompetitif tahun 1980 dari Michael E. Porter adalah contoh bagus tentang keterampilan berpikir kritis dalam tindakan. Porter menggunakan keterampilan evaluatifnya yang kuat untuk mengubah banyak kearifan yang diterima di dunia bisnis. Dengan mengeksplorasi kekuatan dan kelemahan dari argumen yang diterima bahwa kebijakan terbaik bagi perusahaan untuk menjadi lebih sukses adalah dengan fokus pada perluasan pangsa pasar mereka, dia dapat menetapkan bahwa kredibilitas argumen itu cacat.

Tanwar (2013) menjelaskan bahwa terdapat tiga strategi umum yang dijelaskan oleh Michael Porter, strategi ini mencakup dua dimensi, yaitu kekuatan strategis dan lingkup strategis. Porter (1985) mengatakan bahwa strategi ini biasanya digunakan untuk mencapai dan menjaga keunggulan kompetitif. Porter (1985) menjelaskan bahwa lingkup strategi merupakan bagian dimensi permintaan yang dilihat dari ukuran dan komposisi pasar yang dijadikan sebagai target. Kemudian, kekuatan strategis ini merupakan bagian dimensi yang dilihat dari kekuatan atau kompetensi inti dari perusahaan. Tanwar (2013) menjelaskan bahwa Porter melihat dua dimensi tersebut lalu diidentifikasikan dalam dua kompetensi yang menurut Porter adalah yang paling penting yaitu diferensiasi produk dan biaya produk (efisiensi).

Porter (1985) menjelaskan bahwa perusahaan yang memiliki pasar yang luas akan lebih sukses karena mereka melakukan strategi biaya dan perusahaan yang memiliki pasar yang sedikit lebih sukses, karena mereka menggunakan segmentasi pasar yang lebih fokus terhadap ceruk pasar yang ada. Sedangkan, perusahaan yang berada di tengah tidak akan lebih menguntungkan karena mereka tidak memiliki strategi yang digunakan. Porter (1985) menjelaskan bahwa penggabungan beberapa strategi akan sukses hanya dalam satu kasus. Penggabungan strategi segmentasi pasar dengan strategi diferensiasi produk adalah cara yang paling efektif untuk mencocokkan dengan strategi produk perusahaan terhadap karakteristik dari target pasar. Hanya saja, penggabungan biaya dengan diferensiasi ini dilihat sulit untuk diimplementasikan karena adanya potensi konflik antara minimalisasi biaya dan biaya tambahan dari diferensiasi nilai tambah. Berikut ini akan diilustrasikan mengenai dua strategi dari Porter.

\section{Bagan 1. Dua Strategi Porter}

Sirategic Advantage

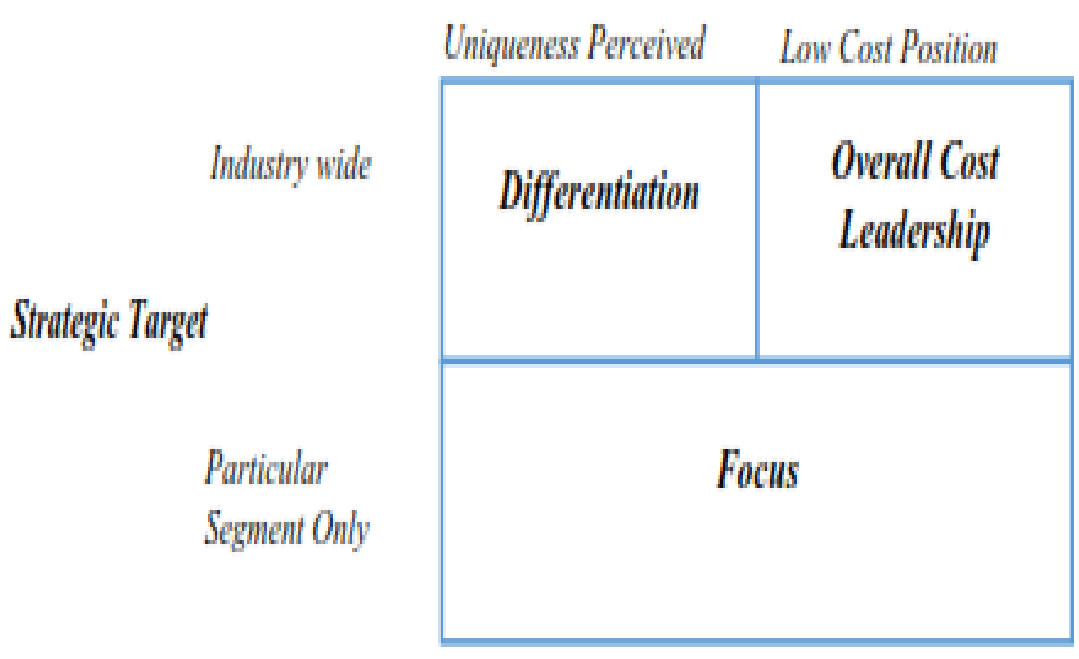


Pada Bagan 1 menjelaskan mengenai strategi umum yang bisa digunakan oleh perusahaan. Posisi perusahaan dalam suatu industri ini diberikan beberapa pilihan untuk mencapai keunggulan bersaing yaitu kepemimpinan biaya dan diferensiasi serta pilihan dalam lingkup kompetitif. Lingkup kompetitif ini menjelaskan mengenai segmen target industri yang luas dan fokus perusahaan terhadap ceruk pasar. Tarwan (2013) menjelaskan bahwa strategi umum ini berguna karena mengkarakteristikan posisi strategi dengan sederhana dan tingkatan yang luas. Porter (1985) menjelaskan bahwa pencapaian keunggulan kompetitif membutuhkan perusahaan untuk membuat pilihan mengenai tipe dan lingkup dari keunggulan kompetitif.

\section{Strategi Kepemimpinan Biaya}

Strategi ini menekankan efisiensi. Porter (1985) menjelaskan bahwa strategi ini dapat membuat perusahaan lebih efisien dengan cara memproduksi dengan volume banyak dari standar produk agar perusahaan bisa mengambil keuntungan dari skala dan kurva pengalaman. Strategi ini memerlukan pertimbangan dari keunggulan pasar, komponen, tenaga kerja atau input penting lainnya agar bisa sukses. Tidak adanya keunggulan ini, strategi yang dilakukan perusahaan akan lebih mudah ditiru oleh kompetitor. Implementasi yang sukses akan memberikan manfaat terhadap kemampuan engineer, desain produk, pengendalian biaya yang ketat, selalu memastikan bahwa biaya tetap berada dalam tingkatan minimum, dan supervise tenaga kerja

Menurut Richard (2016) organisasi yang berupaya menjadi produsen berbiaya terendah dalam suatu industri dapat disebut sebagai mereka yang mengikuti strategi kepemimpinan biaya. Organisasi/perusahaan dengan biaya terendah akan mendapatkan keuntungan tertinggi jika produk yang bersaing pada dasarnya tidak terdiferensiasi, dan dijual dengan harga pasar standar. Perusahaan yang mengikuti strategi ini menekankan pada pengurangan biaya dalam setiap kegiatan dalam rantai nilai (Rumelt, dalam Richard, 2016). Penting untuk dicatat bahwa perusahaan mungkin menjadi pemimpin biaya tetapi itu tidak berarti bahwa produk perusahaan akan memiliki harga yang rendah. Dalam keadaan tertentu, perusahaan dapat mengenakan harga rata-rata sambil mengikuti strategi kepemimpinan biaya rendah dan menginvestasikan kembali keuntungan ekstra ke dalam bisnis (Lynch, dalam Richard, 2016). Contoh perusahaan yang mengikuti strategi kepemimpinan biaya termasuk RyanAir dan EasyJet, di maskapai penerbangan; Airtel and Orange di telekomunikasi Kenya, Fly540, Jumbo Jet, dan maskapai Ethiopian di maskapai Kenya; serta ASDA dan Tesco, di Superstores.

Namun, Jatmiko (Merliana \& Kurniawan, 2016) the cost of leadership merupakan serangkaian tindakan integratif untuk memproduksi dan menawarkan barang atau jasa pada biaya paling rendah terhadap para pesaing dengan ciri-ciri yang dapat diterima oleh para pelanggan. Perusahaan yang memiliki keunggulan biaya menyeluruh dapat memanfaatkan keunggulan ini untuk menetapkan harga rendah atau mengambil margin laba yang lebih tinggi.

\section{Strategi Diferensiasi}

Porter (1985) menjelaskan bahwa diferensiasi memiliki tuntutan pasar yang luas yang melibatkan kreasi dari produk atau pelayanan sebagai keunikan dari industri itu sendiri. Perusahaan nantinya akan membebankan biaya premium terhadap produk tersebut. Diferensiasi ini bisa dilakukan mulai dari desain, brand image, teknologi, fitur, dealers, jaringan, dan pelayanan konsumen. Diferensiasi ini merupakan strategi yang dilakukan agar perusahaan bisa lebih dari rata-rata yang ada dalam bisnis tertentu agar mendapatkan konsumen yang loyal terhadap mereka karena sensitivitas terha- 
dap harga. Peningkatan biaya muncul bisa saja diberikan kepada pembeli. Loyalitas pembeli dapat memberikan suatu masukan baru pada perusahaan untuk mendiferensiasikan suatu masukan baru untuk mengembangkan kompetensi produk. Tanwar (2013) mengatakan bahwa strategi diferensiasi ini bisa meningkatkan keuntungan daripada strategi biaya rendah karena diferensiasi membentuk rintangan baru yang lebih baik. Sedangkan, strategi biaya rendah lebih kepada meningkatkan pasar.

Ketika sebuah perusahaan membedakan produk-produknya, ia seringkali dapat membebankan harga premium untuk produk atau layanannya di pasar. Beberapa contoh umum diferensiasi meliputi tingkat layanan betters kepada pelanggan, kinerja produk yang lebih baik, dan lain-lain. Dibandingkan dengan pesaing yang ada (Henderson, dalam Richard, 2016). Porter (1985) berpendapat bahwa untuk perusahaan yang menggunakan strategi diferensiasi, akan ada biaya tambahan yang harus dikeluarkan perusahaan. Biaya semacam itu dapat mencakup pengeluaran iklan yang tinggi untuk mempromosikan citra merek yang dibedakan untuk produk, yang sebenarnya dapat dianggap sebagai biaya dan investasi. Equity Bank di Kenya, misalnya dibedakan dengan nama merek dan penawaran mereknya seperti sayap untuk terbang, pinjaman kecil dan tidak fleksibel di sepanjang anggota ekuitas (Richard O. M., 2016). Perbedaan memiliki banyak keuntungan bagi perusahaan yang memanfaatkan strategi tersebut. Beberapa area bermasalah mencakup kesulitan pada bagian perusahaan untuk memperkirakan apakah biaya tambahan yang diperlukan untuk diferensiasi sebenarnya dapat dipulihkan dari pelanggan melalui harga premium. Terlebih lagi, strategi diferensiasi yang berhasil dari suatu perusahaan dapat menarik pesaing untuk memasuki segmen pasar perusahaan dan menyalin produk yang dibedakan tersebut (Lynch, dalam Richard, 2016).

\section{Strategi Fokus}

Porter (1985) menjelaskan bahwa strategi fokus mengonsentrasikan perusahaan terhadap beberapa target pasar saja, biasanya disebut dengan strategi fokus atau strategi ceruk. Strategi ini bertujuan untuk fokus terhadap usaha pemasaran pada satu atau dua segmen pasar dan membuat bauran pemasaran yang dikhususkan untuk pasar tersebut shingga perusahaan dapat menemukan kebutuhan target pasar yang lebih baik. Hal ini cocok untuk perusahaan kecil dibandingkan dengan perusahaan besar. Strategi ini digunakan untuk memilih target tertentu yang membutuhkan suatu subtitusi di mana persaingan di dalamnya lemah untuk mendapatkan pengembalian investasi di atas rata-rata. Strategi fokus ini sendiri memiliki dua varian yaitu, 1) fokus terhadap biaya, perusahaan akan mencari keunggulan biaya dari target segmen; dan 2) fokus diferensiasi, perusahaan akan mencari diferensiasi dari target segmen.

Kedua varian pada strategi fokus ini bertumpu terhadap perbedaan antara target segmen dan segmen lainnya dalam industri. Target segmen ini setidaknya harus memiliki pembeli dengan kebutuhan yang tidak biasa atau sistem produksi dan pengiriman yang paling baik di mana target segmen ini berbeda dengan segmen industri lainnya. Fokus biaya ini akan melihat dari perilaku biaya dari beberapa segmen, sementara fokus diferensiasi akan melihat dari kebutuhan khusus pembeli dalam segmen tertentu.

Porter awalnya menyajikan fokus sebagai salah satu dari tiga strategi generik, tetapi kemudian mengidentifikasi fokus sebagai moderator dari dua strategi. Perusahaan menggunakan strategi ini dengan berfokus pada area di pasar di mana terdapat jumlah kompetisi paling sedikit (Pearson, dalam Richard, 2016). Organisasi dapat menggunakan strategi fokus dengan berfokus pada ceruk khusus 
di pasar dan menawarkan produk khusus untuk ceruk itu. Inilah sebabnya mengapa strategi fokus juga kadang-kadang disebut sebagai niche strategy menurut (Lynch, dalam Richard, 2016). Oleh karena itu, keunggulan kompetitif hanya dapat dicapai di segmen target perusahaan dengan menggunakan strategi fokus. Perusahaan dapat menggunakan pendekatan kepemimpinan biaya atau diferensiasi sehubungan dengan strategi fokus. Dalam hal itu, perusahaan yang menggunakan pendekatan fokus biaya akan bertujuan untuk keunggulan biaya di segmen targetnya saja. Jika sebuah perusahaan menggunakan pendekatan fokus diferensiasi, itu akan bertujuan untuk diferensiasi dalam target segmennya saja, dan bukan pasar keseluruhan.

Strategi ini memberikan perusahaan kemungkinan untuk membebankan harga premium untuk kualitas unggul (fokus diferensiasi) atau menawarkan produk dengan harga murah kepada kelompok pembeli kecil dan khusus (fokus biaya). Ferrari dan Rolls-Royce adalah contoh klasik pemain ceruk di industri mobil. Kedua perusahaan ini memiliki ceruk produk premium yang tersedia dengan harga premium (Kiechel, dalam Richard, 2016). Selain itu, mereka memiliki persentase kecil dari worldwide market, yang merupakan ciri khas dari pemain niche. Kelemahan dari strategi fokus adalah ceruk secara karakteristik kecil dan mungkin tidak signifikan atau cukup besar untuk membenarkan perhatian perusahaan. Fokus pada biaya bisa sulit di industri di mana ekonomi skala memainkan peran penting. Ada bahaya nyata bahwa ceruk mungkin menghilang dari waktu ke waktu, karena lingkungan bisnis dan preferensi pelanggan berubah seiring waktu (Ghemawat, dalam Richard, 2016).

\section{Metode Penelitian}

Jenis penelitian yang digunakan dalam penelitian ini adalah deskriptif analisis dengan pendekatan kualitatif. Metode penelitian deskriptif adalah penelitian yang dilakukan untuk mengetahui keberadaan variabel mandiri, baik hanya pada satu variabel atau lebih (variabel yang berdiri sendiri) tanpa membuat perbandingan dan mencari hubungan variabel itu dengan variabel yang lainnya. Metode penelitian deskriptif analisis yang dugunakan untuk menganalisis data dengan cara mendeskripsikan atau menggambarkan data yang telah terkumpul sebagaimana adanya (Sugiyono, 2016).

Data yang digunakan dalam penelitian ini adalah data sekunder. Menurut Sugiyono (2016) sumber data sekunder adalah sumber data yang tidak langsung diberikan datanya kepada pengumpul data misalnya melalui dokumen. Penelitian ini dilakukan di perusahaan Xioami dan perusahaan Vivo. Analisis data yang digunakan adalah analisis SWOT sebagai salah satu langkah yang paling peting dalam memformulasikan strategi. Suryatama, (2014) mengemukakan bawah analisis SWOT adalah sebuah metode yang digunakan untuk mengevaluasi kekuatan, kelemahan, peluang, dan ancaman dalam suatu proyek atau spekulasi bisnis atau proyek yang mengidentifikasi faktor internal dan eksternal yang mendukung dan yang tidak mencapai tujuan.

\section{Analisis SWOT}

\section{Pengertian Analisis SWOT}

Analisis SWOT adalah penilaian menyeluruh terhadap kekuatan (strengths), kelemahan (weakness), peluang (opportunities), dan ancaman (threats) suatu perusahaan (Kotler \& Armstrong, 2008). Atau dengan kata lain SWOT digunakan untuk menilai kekuatan-kekuatan dan kelemahankelemahan eksternal dan tantangantantangan yang dihadapi (Hartono, 2005). SWOT menurut Sutojo (2002) adalah untuk menentukan tujuan usaha yang realistis, sesuai dengan kondisi perusaha- 
an dan oleh karenanya diharapkan lebih mudah tercapai.

Nisak (2004) mengatakan analisis SWOT yakni mencakup upaya-upaya untuk mengenali kekuatan, kelemahan, peluang, dan ancaman yang menentukan kinerja perusahaan. Informasi eksternal mengenai peluang dan ancaman dapat diperoleh dari banyak sumber, termasuk pelanggan, dokumen pemerintah, pemasok, kalangan perbankan, dan rekan diperusahaan lain. Banyak perusahaan menggunakan jasa lembaga pemindaian untuk memperoleh kliping surat kabar, riset di internet, dan analisis tren-tren domestik dan global yang relevan (Daft, 2010).

Selanjutnya, Rangkuti (2006) menjelaskan bahwa analisis SWOT adalah identifikasi berbagai faktor secara sistematis untuk merumuskan strategi perusahaan. Analisis ini didasarkan pada logika yang dapat memaksimalkan kekuatan (strength) dan peluang (opportunity), namun secara bersamaan dapat meminimalkan kelemahan (weakness) dan ancaman (threat). Proses pengambilan keputusan strategi selalu berkaitan dengan pengembangan misi, tujuan, strategi dan kebijakan perusahaan. Dengan demikian, perencanaan strategi harus menganalisis faktor-faktor strategi perusahaan (kekuatan, kelemahan, peluang, dan ancaman) dalam kondisi yang saat ini.

Analisis SWOT membandingkan antara faktor eksternal peluang (opportunity) dan ancaman (threat) dengan faktor internal kekuatan (strenght) dan kelemahan (weakness).

Unsur-unsur SWOT yakni kekuatan (strenght), kelemahan (weakness), peluang (opportunity), ancaman (threat) faktor eksternal dan internal.

Menurut Noor (2014) analisis ini didasarkan pada asumsi bahwa suatu strategi yang efektif akan memaksimalkan kekuatan dan peluang serta meminimalkan kelemahan dan ancaman. Bila diterapkan secara akurat, asumsi sederhana ini mempunyai dampak yang sangat besar atas rancangan suatu strategi yang berhasil dan analisis lingkungan industri menyajikan informasi yang dibutuhkan untuk mengidentifikasi peluang dan ancaman yang ada dalam lingkungan perusahaan.

Menurut Wheelen, dkk (Ramdani, 2019) analisis SWOT merupakan akronim dari strength, weakness, opportunity, dan threat adalah analisis yang menjelaskan faktor-faktor strategis yang memengaruhi suatu perusahaan atau organisasi. SWOT sebagai sebuah alat konsep yang dapat digunakan untuk menerima sebuah gambaran lebih luas melalui formula $\mathrm{SA}=\mathrm{O} /(\mathrm{S}-\mathrm{W}) \quad$ (strategy alternative=opportunity dibagi dengan strength dikurangi weakness).

Menurut Fahmi (Nisak, 2004) untuk menganalisis secara lebih dalam tentang SWOT, maka perlu dilihat faktor eksternal dan internal sebagai bagian penting dalam analisis SWOT, yaitu:

1) Faktor eksternal

Faktor eksternal ini mempengaruhi terbentuknya opportunities and threats $(\mathrm{O}$ dan T). Di mana faktor ini menyangkut dengan kondisi-kondisi yang terjadi di luar perusahaan yang memengaruhi dalam pembuatan keputusan perusahaan. Faktor ini mencakup lingkungan industri dan lingkungan bisnis makro, ekonomi, politik, hukum, teknologi, kependudukan, serta sosial budaya.

2) Faktor internal

Faktor internal ini memengaruhi terbentuknya strenght and weakness ( $\mathrm{S}$ dan W). Di mana faktor ini menyangkut dengan kondisi yang terjadi dalam perusahaan, yang mana ini turut memengaruhi terbentuknya pembuatan keputusan (decision making) perusahaan. Faktor internal ini meliputi semua macam manajemen fungsional, baik dalam pemasaran, keuangan, operasi, sumber daya manusia, penelitian dan pengembangan, sistem informasi manajemen, dan budaya perusahaan (corporate culture). 


\section{Hasil dan Pembahasan}

\section{Perusahaan Xiaomi}

Xiaomi Inc. adalah salah satu perusahaan elektronik terkemuka dari negeri Tiongkok. Xiaomi didirikan pada tahun 2010 oleh Lei Jun, yang kini juga menjabat sebagai CEO dan merupakan salah satu orang terkaya di Tiongkok versi majalah Forbes. Dalam pendiriannya, Xiaomi dibantu berbagai sumber pendanaan oleh investor, seperti Temasek Holdings yang merupakaan perusahaan investasi milik pemerintah Singapura, perusahaan pendanaan modal dari Tiongkok yaitu IDG Modal dan Qiming Venture Partners, serta perusahaan pengembang prosesor yaitu Qualcomm. Menurut situs resmi dari Xiaomi, Xiaomi dapat dengan cepat telah menjadi salah satu perusahaan teknologi terkemuka di Tiongkok. Xiaomi merupakan perusahaan elektronik yang merancang, mengembangkan, menjual smartphone, dan alat elektronik lain untuk para konsumennya. Sejak merilis smartphone pertamanya di bulan Agustus 2011, Xiaomi kini telah berhasil memperoleh pangsa pasar tertinggi di negara asalnya. Xiaomi juga kini memiliki nilai perusahaan lebih dari 10 miliar USD dan telah memiliki lebih dari 3000 karyawan, baik yang berasal dari Tiongkok, Malaysia, Singapura, India, Filipina dan Indonesia.

Pada Agustus 2010, Xiaomi telah meluncurkan firmware berbasis android yang dinamakan MIUI. Pada Agustus 2011, Xiaomi meluncurkan smartphone pertamanya yang diberi nama Mil (Mi One). Tidak tanggung-tanggung, Xiaomi membenamkan prosesor Qualcomm Snapdragon dual-core $1,5 \mathrm{GHz}$ ke dalam Mi One. Sebuah prosesor yang diyakini sebagai prosesor mobile tercepat pada waktu itu. Dan hebatnya lagi, spesifikasi mumpuni yang dimiliki Mi One ditawarkan ke pasar dengan harga yang sangat murah.

Pada tahun 2013, Hugo Barra (ExGoogle Executive) direkrut oleh Xiaomi sebagai Vice President. Perekrutan ini menjadi pertanda bahwa Xiaomi sudah mulai bersiap untuk melakukan ekspansi ke luar negeri. Ekspansi yang pertama kali dilakukan adalah melakukan penjualan di negara sekitar seperti Hongkong dan Taiwan. Pada awal tahun 2014, Xiaomi membuka kantor resmi di Singapura. Pendirian kantor ini menjadi pertanda bahwa Xiaomi sudah mulai melirik pasaran di Asia Tenggara. Keputusan Xiaomi untuk membuka kantor di Singapura berhasil. Smartphone buatan mereka laris manis di negara tersebut. Kemudian Xiaomi melanjutkan ekspansinya ke Malaysia, Filipina, India dan hingga akhirnya sampai ke Indonesia pada bulan September 2014. Di tahun yang sama, Xiaomi merubah domain website resminya dari Xiaomi.com menjadi Mi.com. Xiaomi membeli domain baru dengan nama Mi.com seharga 3,6 juta USD, atau sekitar 44,5 miliar rupiah dan menjadi nama domain termahal yang pernah dibeli perusahaan Tiongkok. Xiaomi juga berencana akan berinvestasi hingga 1 miliar USD atau sekitar 12,3 triliun rupiah untuk membangun konten televisi.

Pada tahun 2015, Xiaomi berencana untuk memperkuat posisinya di India maupun Indonesia dengan target mengalahkan dominasi kompetitornya yaitu Apple dan Samsung. Setelah itu, Xiaomi akan melanjutkan ekspansi ke negara-negara lain seperti Brazil, Meksiko, Rusia, Amerika, dan Eropa. Berikut ini adalah analisis SWOT dari Xiaomi. 
Tabel 1. Faktor Internal dan Eksternal Smartphone Xiaomi

\begin{tabular}{|c|c|c|}
\hline No. & Faktor Internal & \\
\hline 1 & Kekuatan (Strenght) & $\begin{array}{l}\text { a. Salah satu pembuat smartphone terbesar; } \\
\text { b. Smartphone dengan penjualan tertinggi; } \\
\text { c. Xiaomi memiliki keunggulan penentuan harga } \\
\text { terkuat; } \\
\text { d. Produk berkualitas terbaik; } \\
\text { e. Xiaomi memiliki keunggulan pabrikasi dimana } \\
\text { Tiongkok merupakan negara yang terkenal dengan } \\
\text { manufaktur dan mengekspor barang. }\end{array}$ \\
\hline 2 & Kelemahan (Weakness) & $\begin{array}{l}\text { a. Pada beberapa produk masih terbilang sulit } \\
\text { ditemukan pada offline store Xiaomi; } \\
\text { b. Pengeluaran iklan dan pemasaran merek yang masih } \\
\text { rendah; } \\
\text { c. Citra merek dan ekuitas masih termasuk belum } \\
\text { sebaik pesaing. }\end{array}$ \\
\hline No. & Faktor Eksternal & \\
\hline 1 & Peluang (Opportunity) & $\begin{array}{l}\text { a. Xiaomi fokus memprioritaskan memasuki negara- } \\
\text { negara berkembang dan pasar negara; } \\
\text { b. Pendistribusian Xiaomi tidak hanya di online store, } \\
\text { Xiaomi juga mengembangkan pendistribusian ke } \\
\text { offline store resmi Xiaomi; } \\
\text { c. Inovasi dan diferensiasi produk yang terus } \\
\text { berkembang sehingga membuat Xiaomi dapat terus } \\
\text { bersaing, dengan terus mengeluarkan smartphone } \\
\text { yang akan menangkap pangsa pasar; } \\
\text { d. Terjangkaunya harga smartphone Xiaomi dengan } \\
\text { kualitas yang terbaik. }\end{array}$ \\
\hline 2 & Ancaman (Threat) & $\begin{array}{l}\text { a. Kurangnya pusat layanan; } \\
\text { b. Banyaknya pesaing yang memiliki keunggulan yang } \\
\text { sama dengan Xiaomi. }\end{array}$ \\
\hline
\end{tabular}

Setelah dilakukan analisis SWOT pada Xiaomi akan dilakukan analisis berdasarkan tiga bentuk dasar atau strategi generic yang digunakan dalam bersaing, ketiga strategi itu adalah strategi keunggulan biaya, strategi diferensiasi, dan strategi fokus dengan menghasilkan produk yang berbeda dengan pesaing. Berikut merupakan hasil analisis yang didapatkan.

1) Strategi Keunggulan Biaya

Pada penerapan strategi keunggulan biaya maka suatu bisnis dituntut untuk menguasai pangsa pasar yang relatif besar dan memiliki keunggulan bersaing pada efisiensi biaya. Pada Xiaomi ini dapat dilihat sudah menerapkan strategi ini.
Karena dapat dilihat dari harga-harga yang ditawarkan oleh Xiaomi cukup bersaing dan dapat dijangkau oleh konsumen.

2) Strategi Diferensiasi

Diferensiasi ini merupakan strategi yang dilakukan agar perusahaan bisa lebih dari rata-rata yang ada dalam bisnis tertentu, agar mendapatkan konsumen yang loyal terhadap merek karena sensitivitas terhadap harga. Diferensiasi akan membuat suatu produk lebih melekat dibenak konsumen, bahkan cara melakukan diferensiasi pun berbeda untuk setiap perusahaan. Perusahaan yang menerapkan strategi diferensiasi tidak berusaha untuk tampil sebagai produsen 
dengan biaya paling rendah, melainkan menghasilkan suatu produk yang memiliki keunikan sehingga mudah dibedakan dari produk sejenis di pasar.

Pada Xiaomi ini sudah melakukan strategi diferensiasi di mana perusahaan ini melakukan jenis produk yang berbeda dari pesaing, lalu Xiaomi memiliki keunggulan penentuan harga yang terkuat, tidak hanya itu, Xiaomi memiliki keunggulan pabrikasi dimana Tiongkok merupakan negara yang terkenal dengan manufaktur dan mengekspor barang. Hal ini membuat Xiaomi bisa menjadi salah satu perusahaan smartphone terbesar.

Setelah dilakukannya pengamatan dan analisis pada perusahaan Xiaomi dapat diketahui bahwa masih terdapat beberapa kelemahan yang dimiliki perusahaan Xiaomi. Walaupun terdapat beberapa kekuatan namun apabila masuk dalam persaingan bisnis saat ini, perusahaan Xiaomi terbilang masih belum memiliki banyak variasi produk dan citra merek yang bisa membuat konsumen menjadi tertarik dan menjadikan Xiaomi pilihan saat konsumen mencari smartphone yang memuaskan.

\section{Perusahaan Vivo}

Vivo didirikan pada tahun 2009 di Dongguan, Guangdong, China sebagai sub-brand BBK Electronics oleh Shen Wei. Namun, brand Vivo sendiri baru mencuat pada tahun 2012 setelah merilis seri X1 yang diklaim sebagai 2 ponsel paling ramping pada saat itu. Vivo kemudian masuk ke pasar Asia Tenggara, termasuk Indonesia pada tahun 2014. Pada akhirnya, kiprah Vivo di pasar Asia ini benar-benar mengusik kenyamanan vendor besar pada tahun 2015, di mana Vivo sukses masuk 10 besar vendor smartphone dunia dengan marketshare $2,7 \%$.

Pada perjalanannya Vivo tidak hanya mengembangkan produknya pada smartphone saja namun juga pada aksesoris smartphone, perangkat lunak, dan layanan online. Keseriusan Vivo dalam mengembangkan mereknya dibuktikan dengan adanya tujuh pusat penelitian dan pengembangan yang berada di Beijing, Shenzhen, Hanzou, Nanjing, Chang'an di China, serta San Diego dan Sillicon Valley di Amerika Serikat. Memperkenalkan berbagai fitur pada smartphone $\mathrm{V}$-series, $\mathrm{X}$-series, $\mathrm{Y}$-series di berbagai negara, beberapa inovasi yang telah dihasilkan, seperti: Hi-Fi Audio Chips pada smartphone pertama di dunia, Peningkatan resolusi kamera depan pada V-series, teknologi rintisan 5G yang diperkenalkan pada Global TD-LTE Initiative (GTI) Summit 2017, serta Inovasi layar bezel-less FullView Display yang juga dapat dinikmati pada Vivo V7 dan V7+.

Pada kuartal pertama 2017 Vivo mampu menguasai pangsa pasar dunia sebesar 6,8\%, kemudian pada kuartal kedua 2017 Vivo mendapatkan penjualan sebesar 24.3 juta. Hal ini menunjukkan bahwa Vivo memiliki pertumbuhan pasar yang relatif stabil.

Vivo memiliki visi perusahaan yakni untuk menjadi sebuah perusahaan global yang lebih sehat, perusahaan yang bertahan lebih lama. Visi tersebut diwujudkan perusahaan dalam salah satu misinya untuk konsumen yakni menyediakan produk berkualitas dan layanan yang unggul. Misi yang dimiliki Vivo untuk karyawan yakni menciptakan dan memelihara keharmonisan, lingkungan kerja saling menghormati, sementara untuk mitra bisnis Vivo ingin menciptakan satu platform kerjasama yang adil, yang saling menguntungkan dan visi yang terakhir ialah untuk pemegang saham yakni menyediakan above-average returns atas investasi.

Vivo memiliki website resmi di www.vivo.com dengan website tersebut konsumen dapat dengan mudah mencari tahu informasi mengenai produk-produk yang dimiliki oleh Vivo dan konsumen dapat pula menjangkau produk dengan adanya data outlet resmi Vivo yang tersebar di seluruh Asia dan diinformasi- 
kan melalui website tersebut. Berikut ini adalah analisis SWOT dari perusahaan smartphone Vivo.

Tabel 2. Faktor Internal dan Eksternal Smartphone Vivo

\begin{tabular}{|c|c|c|}
\hline No. & Faktor Internal & \\
\hline 1 & Kekuatan (Strenght) & $\begin{array}{l}\text { a. Kualitas mesin yang baik; } \\
\text { b. Garansi resmi; } \\
\text { c. Teknologi dan fitur yang selalu terdepan; } \\
\text { d. Harga terjangkau dengan spesifikasi terbaik. }\end{array}$ \\
\hline 2 & Kelemahan (Weakness) & $\begin{array}{l}\text { a. Branding di lapangan masih terbilang rendah; } \\
\text { b. Loyalitas promotor. }\end{array}$ \\
\hline No. & Faktor Eksternal & \\
\hline 1 & Peluang (Opportunity) & $\begin{array}{l}\text { a. Brand Awareness; } \\
\text { b. Pengalaman konsumen yang telah menggunakan } \\
\text { produk smartphone Vivo; } \\
\text { c. Teknologi dan fitur pesaing yang terbatas; } \\
\text { d. Vendor/ Leasing untuk mempermudah penjualan } \\
\text { kredit. }\end{array}$ \\
\hline 2 & Ancaman (Threat) & $\begin{array}{l}\text { a. Teknologi dan fitur yang masih mudah ditiru oleh } \\
\text { pesaing; } \\
\text { b. Service Center yang terbatas. }\end{array}$ \\
\hline
\end{tabular}

Setelah dilakukannya analisis SWOT pada perusahaan smartphone Vivo maka penulis akan berusaha membahas tiga bentuk dasar strategi generic yang digunakan dalam strategi bersaing. Ketiga strategi itu adalah strategi keunggulan biaya, strategi diferensiasi, dan strategi fokus. Berikut ini adalah hasil analisisnya.

\section{1) Strategi Keunggulan Biaya}

Dalam menerapkan ke strategi keunggulan biaya, maka suatu bisnis dituntut untuk menguasai pangsa pasar yang relatif besar dan memiliki keunggulan bersaing pada efisiensi biaya. Pada perusahaan smartphone Vivo menetapkan strategi keunggulan biaya, produk smartphone Vivo menerapkan harga yang menarik relatif terjangkau dengan keunggulan teknologi dan fitur yang terbaik.

\section{2) Strategi Diferensiasi}

Diferensiasi merupakan strategi yang dilakukan agar perusahaan bisa lebih dari rata-rata yang ada, agar mendapatkan konsumen yang royal terhadap merek, karena sensitivitas terhadap harga/ diferensiasi akan membuat suatu produk lebih melekat di benak konsumen, bahkan cara melakukan diferensiasi tidak berusaha untuk tampil sebagai produsen dengan biaya yang paling rendah, melainkan menghasilkan suatu produk yang memiliki keunikan sehingga produk mudah dibedakan dengan produk pesaing di pasar.

Dalam strategi ini, perusahaan smartphone Vivo melakukan diferensiasi dari sisi kualitas produk yang bagus. Menciptakan diferensiasi produk erat dengan tambahan yang harus dilakukan agar konsumen dapat mengetahui bahwa produk itu berbeda dengan produk lainnya. Jadi untuk menciptakan diferensiasi produk dapat dikatakan membutuhkan dana yang cukup besar. Dengan demikian, perusahaan smartphone Vivo memberikan kualitas mesin yang terbaik dan di setiap unit produk perusahaan Vivo menawarkan teknologi dan fitur yang terbaik dan yang berbeda dari para pesaing. 
3) Strategi Fokus

Pelaku usaha fokus terhadap segmen tertentu namun secara efektif dan efisien memenuhi kebutuhan dan keinginan segmen dan berhasil meningkatkan kepuasan secara optimal. Strategi fokus akan sangat efektif ketika konsumen mempunyai pilihan atau persyaratan tertentu yang dapat dipenuhi oleh pelaku usaha dan ketika pesaing tidak berusaha untuk melakukan spesialisasi dalam segmen konsumen yang sama. Syarat bagi penerapan strategi ini adalah adanya besaran pasar yang cukup (market size), terdapat potensi pertumbuhan yang baik, dan tidak terlalu diperhatikan oleh pesaing dalam rangka mencapai keberhasilannya.

Strategi fokus yang diterapkan perusahaan smartphone berada di pasar tertentu, yaitu konsumen di seluruh dunia dengan tetap memberikan kepuasan berupa kualitas yang terbaik dengan harga yang terjangkau, produk mudah dicari dan di setiap produk perusahaan Vivo menawarkan teknologi dan fitur yang terbaru.

\section{Kesimpulan}

Berdasarkan hasil penelitian yang dilakukan kedua perusahaan smartphone telah melakukan strategi Porter's Generic Strategy dengan baik. Pada perusahaan Xiaomi dan Vivo telah menerapkan strategi keunggulan biaya dan strategi diferensiasi dengan baik oleh dua perusahaan smartphone tersebut. Pada strategi fokus perusahaan Vivo berada pada pasar tertentu yaitu konsumen di seluruh dunia dengan tetap memberikan kepuasan berupa dapat memiliki smartphone dengan harga terjangkau, teknologi dan fitur yang terbaik di setiap produknya. Sedangkan secara SWOT perusahaan Xiaomi lebih baik dari perusahaan Vivo, karena perusahaan Xiaomi telah memakai analisis SWOT dengan baik dan lengkap dimana perusahaan Xiaomi akan lebih mudah untuk memasuki pasar dan bersaing dengan pesaing. Terakhir disarankan penelitian di masa yang akan datang mempertimbangkan dan juga mempelajari bagaimana masalah berkembangan strategi dari berbagai perusahaan smartphone tidak hanya Vivo dan Xiaomi, dan mengembangkan analisis strategi dengan analisis matrik SWOT.

\section{Daftar Pustaka}

Belton, P. (2017). An Analysis of Michael E. Porter's Competitive Strategy. London: Macat Library.

Daft, R. L. (2010). Era Baru Manajemen. Jakarta: Salemba Empat.

Hartono, J. (2005). Sistem Informasi Strategik untuk Keunggulan Kompetitif. Yogyakarta: Andi Offset.

Kotler, P. (2005). Manajemen Pemasaran. Klaten: PT Intan Sejati Klaten.

Kotler, P., \& Armstrong, G. (2008). Prinsip-prinsip Pemasaran Jilid 1. Jakarta: Erlangga.

Kraus, S., Reiche, B. S., \& Reschke, C. H. (2007). Implications of strategic planning in SMEs for international entrepreneurship research and practice. European Research and Practice, 32(6), 110-127. Diakses dari

https://d1wqtxts1xzle7.cloudfront.n et/49217755/Implications-of-

strategic-planning-in-

$\underline{\text { SMEs.pdf? } 1475169352=\& \text { response }}$ -content-

disposition=inline $\% 3 \mathrm{~B}+$ filename $\%$

3DImplications of Strategic Plann

ing in_SM.pdf\&Expires $=16043418$

$57 \&$ Signature $=Q 45 \mathrm{vdvW} 73 \mathrm{~d} 8 \mathrm{CkN}$

9KphoEtIFlm7vcgqugIM55gxNCK

TtCYu3 xxhv5awarLiL-NaKIwu6-

7AMfJmKQkuAyGL5anBLdplLy-

8qfL8ZIRrnRjCr7P8kPdOHQONkj

ZTraPfbFNRFzfcdq6pJdaho40Wy7

8cBLmSy9pZt3jma5R63nDsnuj-

EGIMOxXFXE3u7xbur1haEwP0L

PcCUmGlB5cbXeZfffrHFYjV6fj q 
7flCvkTNKSdWQGxquNF8hhkBV nuppQJaycYRmkfJlB94slodDKRO Kn90XFVGNMaBLgfkyOtMQcOl vG4noHiBe0MUKElqHBNQIxo6t7 tHC28px9QPvw \& Key-Pair$\underline{\mathrm{Id}=\text { APKAJLOHF5GGSLRBV4ZA }}$

Merliana, V., \& Kurniawan, A. (2016). Pengaruh Strategi Biaya Rendah dan Diferensiasi terhadap Keberhasilan PT Tahu Tauhid. Jurnal Manajemen Maranatha, 15(2). 216-242. doi: https://doi.org/10.28932/jmm.v15i2. $\underline{16}$

Nisak, Z. (2004). Analisis SWOT Untuk Menentukan Strategi Kompetitif. Jurnal Ekbis, 9(2), 469-476. Diakses dari

http://www.academia.edu/download /50582994/4.pdf

Noor, S. (2014). Penerapan Analisis SWOT dalam Menentukan Strategi Pemasaran Daihatsu Luxio di Malang (Studi Kasus pada PT. Astra Internasional Tbk. - Daihatsu Malang). Jurnal INTEKNA: Informasi Teknik dan Niaga, 14(2), 102-209. Diakses dari https://ejurnal.poliban.ac.id/index.p hp/intekna/article/view/181

Porter, M. (1985). Competitive Advantage. New York: The Free Press.

Ramdani, D. (2019). Formulasi Strategi Pengembangan Sumber Daya Manusia Perawatan Pesawat Terbang. Organum: Jurnal Saintifik Manajemen dan Akuntansi, 2(1), 4661. doi: https://doi.org/10.35138/organum.v $\underline{2 \mathrm{i} 1.56}$

Rangkuti, F. (2006). Analisis SWOT Teknik Membedah Kasus Bisnis. Jakarta: PT Gramedia Pustaka Utama.

Rangkuti, F. (2013). Strategi Promosi yang Kreatif. Jakarta: Gramedia Pustaka Utama.

Richard, O. M. (2016). What is Porter Generic Strategies Analysis?. Diakses dari https://www.academia.edu/2855999 0/WHAT_IS_PORTERS_GENERI C_STRATEGIES_ANALYSIS

Sugiyono, P. (2016). Metode Penelitian Kuantitatif, Kualitatif, dan $R \& D$. Bandung: Alfabeta.

Suryatama, E. (2014). Analisis SWOT. Bandung: Kata Pena.

Sutojo, S. \& Kleinsteuber, F. (2002). Strategi Manajemen Pemasaran, Cetakan Pertama. Jakarta: Damar Mulia Pustaka.

Tanwar, R. (2013). Porter's Generic Competitive. IOSR Journal of Business and Management, 15(1), 11-17. Diakses dari https://sswm.info/sites/default/files/ reference_attachments/TANWAR\% 202013\%20Porter\%E2\%80\%99s\% 20Generic\%20Competitive\%20Stra tegies.pdf

Tjiptono, F. (2010). Manajemen Pemasaran: Strategi Pemasaran. Yogyakarta: ANDI. 